CONSTITUTION OF "THE SOCIETY OF FIRST SETTLERS OF MUSUATINE UOUNTY, IOWA."

Organized Febreary 9th, 1856.

At a meeting of the first settlers of Muscatine county, held at the lecture room of the Congregational Church, on the evening of February 9th, 1§56 , the following Constitution and Preamble was adopted:

We, the subscribers hereto, being the first settlers or immigrants, who made Muscatine, (formerly Bloomington,) and Muscatine county, in the territory of (Michigan. Wisconsin and) Iowa our home, and who commenced the building and improvement of the prosperous city and county of which we are still inhabitants, do hereby agree to form ourselves into a Society to be called and known as "The Socrety of First Settlers of Muscatine Countr, Iowa," and adopt the following as our form of organization :

\title{
ARTICLE I.
}

of Members.-The Society shall consist of those first settlers who, having emigrated from their former homes, came to Muscatine, (formerly Bloomington,) Iowa, and Muscatine county, Iowa, and made their homes here, previous to the first day of January. A. D. 1840, as well as those ritizens of the city or county who settled in Iowa before said day, together with their descendants for all time to come.

\section{SECTION II.}

Of Membership Continued.-Each and every of such first settlers who shall subscribe his name to these Articles, shall be deemed a member of the Society.

\section{ARTICLE II.}

Objects. - The design of this organization is, and shall be, to collest and preserve the names of the persons who com- 
menced and made the first settlement in Muscatine county, and who were the pioneers of civilization of this point on the west bank of the Father of Waters, male and female, including all who settled here previous to the first day of January, A. D. 1840 , the State or county and town from whence they came, their age, profession, trade or occupation; to collect and preserve a true history of the first settlement, the progress thereof, interestiug facts, incidents thereto, anecdotes, and peculiar characteristics of the persons who composed the first settlements. Also, to make and keep a record of the deaths, marriages, and removals by emigration, and, in short, by all proper means, to collect and preserve for the future, the facts and circumstances of the history of the first settlement of Muscatine, and of the tirst settlers.

SECTION II.

As it is also a prominent feature of the design of this Association to hold in sacred regard that social feeling and fellowship which is peculiar to pioneer life, and should be only the more matured and refined, by growth of population and the increase of civilized associations, the wives, daughters and other female relatives of members shall be held and deemed honorary membere of this Society.

\section{SECTION III.}

Anniversary.-To the end that this feature of our organization may be more publicly manifested, there shall be an Anniversary Meeting of the members of this Society, to be held at such time as the by-laws shall prescribe, and at such place in the city of Muscatine as may be agreed upon by a majority of the active members, and to be conducted in such manner as may by such majority be deemed most advisable.

\section{ARTICLE III.}

Of Finances.-For the purpose of procuring books of record and other things necessary to the accomplishment of the designs of the Society, such means as may be proper, shall be provided by the by-laws, hereafter to be adopted. 


\section{ARTICLE IV.}

Of Officers and Elections.-The officers of this Society shall consist of a President, Vice President and Secretary, to be elected annually at the Anniversary Meeting.

This Society then proceeded to the election of officers, whereupon the following gentlemen were chosen to office:

For President, Jos. Williams, Sr.; for Vice President, Thomas Burdett; for Secretary, Theodore S. Parvin.

\section{"HAWKEYE PIONEER ASSOCIATION OF DES MOINES COUNTY, IOWA."}

ORGANIZED JANUARY 2D, 1858.

\section{CONSTITUTION.}

\section{ARTICLE I.}

This Association is originated for the purpose of commemorating by an annual celebration, and otherwise, (as may be directed by the By-Laws,) the early settlement of Iowa by the White Inhabitants.

\section{ARTICLE II.}

The condition of membership shall be a residence in Iowa prior to June $1 s t, A . D .1840$, (the anniversary day of the surrender by the Indians to the Whites of the "Black-Hawk Purchase," being June 1st, A. D. 1833, ) and a resident of Des Moines County at the time of signing the Constitution; also, the payment of one dollar and subscription to this Constitution:

Provided, however, That the term of membership may be changed at any regular meeting of the members:

Provided, further, That this Association may change or 
Copyright of Annals of Iowa is the property of State of Iowa, by \& through the State Historical Society of Iowa and its content may not be copied or emailed to multiple sites or posted to a listserv without the copyright holder's express written permission. However, users may print, download, or email articles for individual use. 